$\begin{array}{cc}\text { ACADEMIA ROMÂNĂ } & \text { Rev. Roum. Chim., } \\ \mathbf{2 0 2 0}, \text { 65(10), 885-891 } & \text { DOI: 10.33224/rrch.2020.65.10.03 } \\ & \text { Revue Roumaine de Chimie } \\ \text { http://web.icf.ro/rrch/ } & \end{array}$

\title{
ULTRASOUND-ASSISTED SYNTHESIS AND ANTIMICROBIAL EVALUATION OF SOME NOVEL BENZOXAZINONYLHYDRAZONE DERIVATIVES
}

\author{
Naouel CHETTIBI, Houria BENTOUMI and Messaoud LIACHA* \\ Laboratory of Synthesis and Organic Biocatalysis (LSBO), Organic Synthesis and Medicinal Chemistry Group, \\ BADJI Mokhtar-Annaba University, P.O. Box 12, Annaba 23000, Algeria
}

Received June 1, 2019

\begin{abstract}
Some new benzoxazinonylhydrazone analogs derived from substituted benzaldehydes and benzoxazin-3(4H)-one pharmacophore have been synthesized by simple and efficient methods, using ultrasound (US) irradiations as well as conventional thermal heating $(\mathrm{CTH})$. The treatment of the benzoxazinonylhydrazide (3) with the corresponding aromatic aldehyde, resulted in the formation of benzoxazinonylhydrazones (4a-4f) in good yields and short reaction times. The proposed structures of the obtained hydrazone compounds were identified and elucidated on the basis of FT-IR and nuclear magnetic resonance $\left({ }^{1} \mathrm{H}-\mathrm{NMR}\right.$ and $\left.{ }^{13} \mathrm{C}-\mathrm{NMR}\right)$ spectroscopy. The

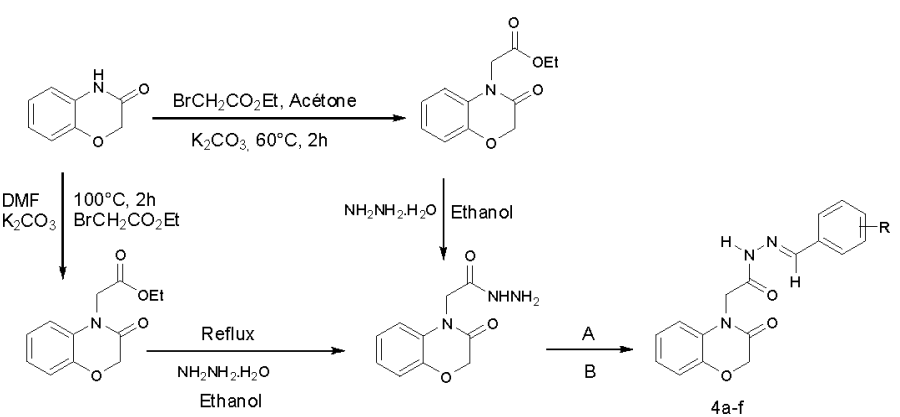
synthesized compounds were screened in vitro for their antibacterial and antifungal activities against three types of bacteria $(S$. aureus, E. coli, $P$. aeruginosa) and one type of fungi (C. albicans), respectively, by disc diffusion method. All of these hydrazone compounds exhibited remarkable antifungal activity and very moderate antibacterial activity.
\end{abstract}

\section{INTRODUCTION}

The appearance of multi-drug resistant microbial pathogens is due to the extensive use of antibiotics. ${ }^{1}$ The rapidly increasing of antimicrobial resistance problem shown by some species of microorganism to multiple antimicrobial drugs reported in recent years, requiring the discovery of new molecules. Thus, there is urgency for the discovery of new chemical entities with enhanced activity profiles. Among the many approaches for the discovery of new drugs, an alternative approach for the development of novel chemotherapeutic agents is based on the concept of modifying the chemical structure of the existing lead compounds.
The remarkable importance of nitrogen heterocycles, such as hydrazides-hydrazones has been the focus of several recent published research works. $^{2-4}$ They have been largely investigated and extensively studied by both experimental and computational methods, ${ }^{5-7}$ that can help in the conception and development of novel bioactive molecules and drug entities. Furthermore, some substituted hydrazones have been the subject of particular consideration, because it is well known that Schiff bases generated from hydrazides produce hydrazone derivatives, and lead usually to an iminic structure, ${ }^{8}$ in both solution and the solid state. $^{9} \quad$ Hydrazones derived from substituted benzaldehydes often exhibit diverse and important

\footnotetext{
${ }^{*}$ Corresponding author: m_liacha@yahoo.fr ; messaoud.liacha@univ-annaba.dz
} 
biological properties, and some of them have considerable potential for pharmacological applications. They were also reported to have lower toxicity than hydrazides because of the blockage of the amino group. ${ }^{10}$ They have also been found to have invaluable medicinal applications including a wide range of pharmacological effects and biological activities, such as antibacterial activity against various pathogenic bacterial strains ${ }^{11-12} \mathrm{We}$ noted that pyridazine derivatives, for example, have been reported to posses various biological activities. ${ }^{13-15}$ Therefore, a large number of this type of products have been prepared, and several methodologies have been already reported for their synthesis via condensation of hydrazides with various suitably substituted benzaldehydes. ${ }^{16-20}$

In recent time, many research studies directed towards the development of new greener and ecofriendly methodologies, for the synthesis of heterocyclic compounds, under non-conventional energy source have received considerable interest because of growing environmental concerns. In this optic, the use of sonication has emerged over recent years as one of the most powerful strategies for green and sustainable supports in organic synthetic chemistry. ${ }^{21-25}$ Thus, in addition to the main requirements mentioned above, it has been used in various organic transformations. Ultrasound-mediated synthesis of interesting heterocyclic bioactive compounds has produced many research studies since its discovery. Several methods reported in the literature have mentioned that many important bioactive molecules can easily be synthesized, from readily available starting materials under ultrasonic irradiations. $^{26,27}$ For example, I. I. Mangalagiu et $a l^{28-32}$ in their recently published research papers have presented several contributions concerning the chemical applications of ultrasound irradiation "Sonochemistry", in the synthesis of a variety of biologically important azaheterocyclic systems. As a result, ultrasound-assisted synthesis constitutes an especially attractive synthetic strategy, since they provide simple access to a large number of organic compounds with diverse substitution patterns.

1,4-Benzoxazin-3-(4H)-one derivatives, on the other hand, are known to possess diverse interesting biological activities such as antimicrobial, ${ }^{33-36}$ anticancer, ${ }^{37}$ herbicidal, ${ }^{38}$ non-steroidal anti-inflammatory $^{39,40}$ and neuroprotective antioxidants. ${ }^{41-42}$ Thus, a large number of compounds based on benzoxazinone scaffold has been described and evaluated for their antifungal and antibacterial activities. ${ }^{43-46}$ The Structure Activity Relationships (SAR) of these compounds has also been investigated. $^{47}$
In this context, and in an effort to pursue the study of the structure-activity relationships of general structure $\mathrm{A}$, we report in this research study, an efficient eco-friendly synthesis and in vitro antibacterial as well as antifungal activities of some novel benzoxazinonic hydrazone derivatives (Figure 1, General structure A).

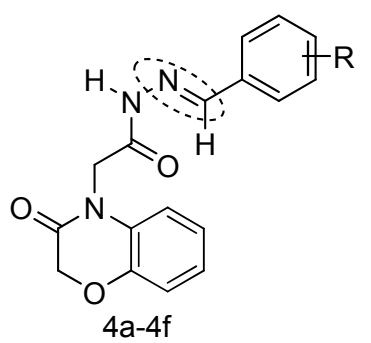

Fig. 1 - General structure A.

\section{EXPERIMENTAL}

\section{General}

Melting points have been determined in open capillary tubes and were uncorrected. The structure of synthesized compounds were characterized through FT-IR, ${ }^{1} \mathrm{H}$ and ${ }^{13} \mathrm{C}-\mathrm{NMR}$ spectral studies and evaluated for their antibacterial as well as antifungal activities by disc diffusion method, using Mueller-Hinton agar medium under described standard conditions. ${ }^{48}$ The NMR spectra were recorded in solutions on a Bruker AC 400 spectrometer using dimethylsulfoxide- $\mathrm{d}_{6}$ and chloroform $\mathrm{CDCl}_{3}$ as solvents with TMS as internal standard, with chemical shifts reported as ( $p p m)$. Analytical thin layer chromatography was performed with commercial silica gel plates 60 F254 (Merck) and visualized with UV light, using ethylacetate/cyclohexane $(8: 2, \mathrm{v} / \mathrm{v})$ solvent system as eluent. Ultrasound assisted reactions were carried out using a FUNGILAB ultrasonic bath with a frequency of $40 \mathrm{kHz}$ and a nominal power of $250 \mathrm{~W}$. The reactions were carried out in an open glass tube (diameter: $25 \mathrm{~mm}$; thickness: $1 \mathrm{~mm}$; volume: $20 \mathrm{~mL}$ ) at room temperature. The starting compound $2 \mathrm{H}-$ benzo[b][1,4]oxazin-3(4H)-one (1) was prepared according to published protocol, ${ }^{33 a}$ and was used in the next step without any further purification.

\section{Methods and procedures for the synthesis of ethyl (3-0xo-2,3-dihydro-4H-1,4-benzoxazin-4-yl)acetate (2)}

The ethyl (3-oxo-2,3-dihydro-4H-1,4-benzoxazin-4-yl)acetate (2) has been previously reported. We have prepared and compared this compound from $2 H$-benzo[1,4]oxazin-3(4H)one (1) and ethyl bromoacetate in two different conditions. The obtained compound was then recrystalized from ethanol to give the desired product. The melting points as well as spectroscopic data of this ethyl ester derivative are in accordance with published data. ${ }^{33 \mathrm{~b}}$

Method A: A mixture of benzoxazin-3(4H)-one (2g, $13 \mathrm{mmol})$ and ethyl bromoacetate $(3.34 \mathrm{~g}, 20 \mathrm{mmol})$ in the presence of anhydrous $\mathrm{K}_{2} \mathrm{CO}_{3}(3.59 \mathrm{~g}, 26 \mathrm{mmol})$ was dissolved in dry acetone and was stirred at $60^{\circ} \mathrm{C}$ for $2 \mathrm{~h}$. The progress of the reaction was monitored by TLC. After the completions of the reaction, the reaction mixture was filtered and the filtrate evaporated under reduced pressure. The residue obtained was 
recrystallized from ethanol to give the suitable compound as a white solid.

Method B: Compound (2) was synthesized in the similar manner by a mixture of benzoxazin-3(4H)-one $(2 \mathrm{~g}, 13 \mathrm{mmol})$, ethyl bromoacetate $(2.67 \mathrm{~g}, 16 . \mathrm{mmol}), \mathrm{K}_{2} \mathrm{CO}_{3}(0.10 \mathrm{~g}$, $14.37 \mathrm{mmol}$ ) in DMF as solvent, and the reaction was stirred at $100^{\circ} \mathrm{C}$ for $2 \mathrm{~h}$. At the end of this period, the mixture was diluted with water. The separated solid formed was filtered, washed repeatedly with water and recrystallized from ethanol to give the desired compound, which is in any point identical to that found by method $\mathbf{A}$.

Compounds $\mathbf{2}$ (method $\mathbf{A}$ and method $\mathbf{B}$ ) was obtained as white solid. Yield: method A (84\%) and method B (82\%); Mp 81-82 ${ }^{\circ} \mathrm{C}$. IR $\left(\mathrm{KBr}, \mathrm{cm}^{-1}\right): 1738,2915,2983 .{ }^{1} \mathrm{H}-\mathrm{NMR}(400$ MHz, DMSO- $\left.d_{6}\right): \delta=1.26-1.29$ (t, $3 \mathrm{H}, \mathrm{CH}_{2}-\mathrm{CH}_{3}, \mathrm{CH}_{3}$ ), 4.214.27 (q, $\left.2 \mathrm{H},-\mathrm{CH}_{2}-\mathrm{CH}_{3}, \mathrm{CH}_{2}\right)$ 4.65-4.68 (d, $4 \mathrm{H}, \mathrm{CH}_{2} \mathrm{COOEt}$, -NCO- $\left.\mathrm{CH}_{2} \mathrm{O}-,{ }_{2} \mathrm{CH}_{2}\right), 6.74-7.26(\mathrm{~m}, 4 \mathrm{H}, \mathrm{Ar}-\mathrm{H}) .{ }^{13} \mathrm{C}-\mathrm{NMR}$ $\left(100 \mathrm{MHz}, \mathrm{CDCl}_{3}\right): 167.91(\mathrm{C}=\mathrm{O}), 165.04(\mathrm{C}=\mathrm{O}), 145.2$, $128.76,124.37,123.06,117.33,114.53$ (aromatic carbons), $67.62\left(\mathrm{CH}_{2}\right), 62.00\left(\mathrm{CH}_{2}\right), 43.07\left(\mathrm{CH}_{2}\right), 14.27\left(\mathrm{CH}_{3}\right)$.

Synthesis of 2-(3-oxo-2H-benzo[b][1,4]oxazin-4(3H)yl)acetohydrazide (3)

A solution of the ethyl 2-(3-oxo-2H-benzo[b][1,4]oxazin$4(3 H)$-yl $)$ acetate ester (2) $(2.55 \mathrm{~g}, 11 \mathrm{mmol})$ in absolute ethanol was refluxed with hydrazine hydrate $(2.75 \mathrm{~g}, 55 \mathrm{mmol})$ for $3 \mathrm{~h}$, monitored by TLC until completion. The solid residu was filtered out and dried to isolate the corresponding pure 2-(3-oxo-2H-benzo[b][1,4] oxazin-4(3H)-yl)acetohydrazide.

Compound 3 was obtained as a white solid. Yield: 83\%; Mp: $171-173^{\circ} \mathrm{C}$. IR $\left(\mathrm{KBr}, \mathrm{cm}^{-1}\right): 1593,1670,1693,2850$, 2893, 2920, 3055, 3217, 3259, 3298, 3332. ${ }^{1} \mathrm{H}-\mathrm{NMR}(400$ MHz, DMSO-d6): $\delta=4.66-4.69\left(\mathrm{~d}, 4 \mathrm{H}, \mathrm{CH}_{2} \mathrm{CONHNH}_{2}\right.$, $\left.\mathrm{NCO}-\mathrm{CH}_{2} \mathrm{O}-, 2 \mathrm{CH}_{2}\right), 4.27-4.28\left(\mathrm{~d}, 2 \mathrm{H}, \mathrm{NH}_{2}\right), 6.89-7.03(\mathrm{~m}$, $4 \mathrm{H}, \mathrm{Ar}-\mathrm{H}), 8.00(\mathrm{~s}, \mathrm{H}, \mathrm{NH}) .{ }^{13} \mathrm{C}-\mathrm{NMR}\left(100 \mathrm{MHz}, \mathrm{CDCl}_{3}\right)$ : $165.9(\mathrm{C}=\mathrm{O}), 164.12(\mathrm{C}=\mathrm{O}), 144.43,128.74,123.41,122.35$, 116.23, 115.07 (aromatic carbons), $66.82\left(\mathrm{CH}_{2}\right), 42.28\left(\mathrm{CH}_{2}\right)$.

General procedure for the synthesis of $N^{\prime}$-(substituted benzylidene)-2(3-oxo-2H-Benzo[b][1,4]oxazin-4(3H)yl)acetohydrazides $\mathbf{( 4 a - 4 f )}$

Conventional method (method A): Substituted aromatic aldehyde derivatives ( 1.0 equiv., $0.23 \mathrm{mmol}$ ) dissolved in pure ethanol, was mixed with a boiling solution of acetohydrazide 3 (50 $\mathrm{mg}, 0.23 \mathrm{mmol})$ in the same solvent. The resulting mixture was stirred under reflux conditions for 35 in the presence of a catalytic amount of glacial acetic acid (2-3 drops). After the completion monitored by TLC using ethylacetate/cyclohexane $(8: 2, \mathrm{v} / \mathrm{v})$ as eluent, the formed product was filtered off, washed with cold ethanol and then dried. The product was in addition purified.

Ultrasound method (method B): The procedure was similar to that described in conventional method, except that the mixture was placed in an open glass tube and exposed to ultrasound irradiation ( $40 \mathrm{kHz}$ and nominal power $250 \mathrm{~W}$ ) at room temperature, under catalyst-free condition for the appropriate time until completion of the reaction (monitored by TLC). The resulting solid was collected by filtration and purified.

$N^{\prime}$-(2-hydroxybenzylidene)-2-(3-oxo- $2 \mathrm{H}$ -

benzo[b] [1,4]oxazin-4(3H)-yl)acetohydrazide (4a)

Yellow powder; Yield: method A $(88 \%)$ and method B (94\%); Mp: $270-271^{\circ} \mathrm{C}$. IR (KBr, cm $\left.{ }^{-1}\right): 1573,1608,1622$, 1693, 2850, 2943, 3074, 3425. ${ }^{1} \mathrm{H}-\mathrm{NMR}$ (400 MHz, DMSO$\left.d_{6}\right): \delta 4.78\left(\mathrm{~s}, 2 \mathrm{H}, \underline{\mathrm{CH}}_{2} \mathrm{CONHNH}-, \mathrm{CH}_{2}\right), 5.05$ (s, $2 \mathrm{H},-\mathrm{NCO}-$ $\left.\mathrm{CH}_{2} \mathrm{O}-, \mathrm{CH}_{2}\right), 8.85(\mathrm{~s}, 1 \mathrm{H}, \mathrm{N}=\mathrm{CH}$, azomethine), $8.36(\mathrm{~s}, 1 \mathrm{H}$, $\mathrm{N}-\mathrm{H}), 6.87-7.78(\mathrm{~m}, 8 \mathrm{H}, \mathrm{Ar}-\mathrm{H}), 11.66(\mathrm{~s}, 1 \mathrm{H}, \mathrm{OH}) .{ }^{13} \mathrm{C}-\mathrm{NMR}$ $(100 \mathrm{MHz}, \mathrm{DMSO}-d 6): \delta 168.00(\mathrm{C}=\mathrm{O}), 165.07(\mathrm{C}=\mathrm{O}), 163.70$
$(\mathrm{N}=\mathrm{C}), \quad 157.74 ， 147.78 ， 145.06 ， 131.97 ， 131.73 ， 129.56$, $129.47,126.83,123.16,120.56,117.01,115.98$ (aromatic carbons), $67.44\left(\mathrm{CH}_{2}\right), 69.92\left(\mathrm{CH}_{2}\right)$.

$\mathrm{N}^{\prime}-(5$-chloro-2-hydroxybenzylidene)-2-(3-oxo- $2 \mathrm{H}$ benzo[b] [1,4]oxazin-4(3H)-yl)acetohydrazide (4b)

Yellow powder; Yield: method A $(74 \%)$ and method B (86\%); Mp: $290-291^{\circ} \mathrm{C}$. IR $\left(\mathrm{KBr}, \mathrm{cm}^{-1}\right): 756,1701,1662$, $1608,2981,3082,3433 .{ }^{1} \mathrm{H}-\mathrm{NMR}\left(400 \mathrm{MHz}, \mathrm{DMSO}-d_{6}\right): \delta$ 4.77 (s, 2H, $\left.\underline{\mathrm{CH}}_{2} \mathrm{CONHNH}-, \mathrm{CH}_{2}\right), 5.09$ (s, 2H, -NCO- $\mathrm{CH}_{2} \mathrm{O}-$, $\left.\mathrm{CH}_{2}\right), 8.42(\mathrm{~s}, 1 \mathrm{H}, \mathrm{N}=\mathrm{CH}$, azomethine $), 8.29(\mathrm{~s}, 1 \mathrm{H}, \mathrm{N}-\mathrm{H})$, 6.91-7.80 (m, 7H, Ar-H), $11.73(\mathrm{~s}, 1 \mathrm{H}, \mathrm{OH}) .{ }^{13} \mathrm{C}-\mathrm{NMR}$ (100MHz, DMSO-d6): $\delta 168.30(\mathrm{C}=\mathrm{O}), 165.05(\mathrm{C}=\mathrm{O}), 163.45$ $(\mathrm{N}=\mathrm{C}), \quad 155.63,145.07,140.31,131.11,129.55,123.93$, $123.76,123.14,122.49,118.40,116.02,115.98$ (aromatic carbons), $67.44\left(\mathrm{CH}_{2}\right), 75.92\left(\mathrm{CH}_{2}\right)$.

$N^{\prime}$-(3,5-di-tert-butyl-2-hydroxybenzylidene)-2-(3-oxo- $2 \mathrm{H}$ benzo[b] [1,4]oxazin-4(3H)-yl)acetohydrazide (4c)

Yellow powder; Yield: method A $(55 \%)$ and method B (60\%); Mp: $226-227^{\circ} \mathrm{C}$. IR $\left(\mathrm{KBr}, \mathrm{cm}^{-1}\right): 1589,1612,1670$, 1687, 2908, 2962, 3051, 3232, 3440. ${ }^{1} \mathrm{H}-\mathrm{NMR}(400 \mathrm{MHz}$, DMSO-d6): $\delta 1.48 \quad\left(\mathrm{~s}, \quad 18 \mathrm{H}, \quad 6 \quad \mathrm{CH}_{3}\right), 4.75 \quad(\mathrm{~s}, \quad 2 \mathrm{H}$, $\mathrm{CH}_{2} \mathrm{CONHNH}-, \mathrm{CH}_{2}$ ), 5.17 (s, $2 \mathrm{H},-\mathrm{NCO}-\mathrm{CH}_{2} \mathrm{O}-, \mathrm{CH}_{2}$ ), 8.49 (s, 1H, N=CH, azomethine), $9.18(\mathrm{~s}, 1 \mathrm{H}, \mathrm{N}-\mathrm{H}), 7.02-7.95(\mathrm{~m}$, $6 \mathrm{H}, \mathrm{Ar}-\mathrm{H}), 11.28(\mathrm{~s}, 1 \mathrm{H}, \mathrm{OH}) .{ }^{13} \mathrm{C}-\mathrm{NMR}(100 \mathrm{MHz}, \mathrm{DMSO}-$ d6): $\delta 169.53(\mathrm{C}=\mathrm{O}), 168.31(\mathrm{C}=\mathrm{O}), 168.08(\mathrm{~N}=\mathrm{C}), 165.24$, $146.03,145.74,145.10,145.05,143.19,123.88,122.82$, $117.12,116.95,115.43,114.83$ (aromatic carbons), 82.39 (C), $77.46(\mathrm{C}), 74.90\left(\mathrm{CH}_{2}\right), 67.58\left(\mathrm{CH}_{2}\right), 43.11\left(\mathrm{CH}_{3}\right), 40.15$ $\left(\mathrm{CH}_{3}\right), 33.64\left(\mathrm{CH}_{3}\right), 31.45\left(\mathrm{CH}_{3}\right), 29.42\left(\mathrm{CH}_{3}\right), 25.41\left(\mathrm{CH}_{3}\right)$.

$N^{\prime}$-(3,5-di-tert-butyl-4-hydroxybenzylidene)-2-(3-oxo- $2 \mathrm{H}$ benzo[b] [1,4]oxazin-4(3H)-yl)acetohydrazide (4d)

Yellow powder; Yield: method A $(68 \%)$ and method B (91\%); Mp: $240-241^{\circ} \mathrm{C}$. IR ( $\left.\mathrm{KBr}, \mathrm{cm}^{-1}\right)$ : $1577.66,1608.52$, 1681.81, 2954.74, 3433.06. ${ }^{1} \mathrm{H}-\mathrm{NMR}$ (400 MHz, DMSO-d6): $\delta 1.48\left(\mathrm{~s}, 18 \mathrm{H}, 6 \mathrm{CH}_{3}\right), 4.79\left(\mathrm{~s}, 2 \mathrm{H}, \mathrm{CH}_{2} \mathrm{CONHNH}-, \mathrm{CH}_{2}\right)$, $5.27\left(\mathrm{~s}, 2 \mathrm{H},-\mathrm{NCO}-\underline{\mathrm{CH}}_{2} \mathrm{O}-, \mathrm{CH}_{2}\right), 8.59(\mathrm{~s}, 1 \mathrm{H}, \quad \mathrm{N}=\underline{\mathrm{CH}}$, azomethine $), 9.28(\mathrm{~s}, 1 \mathrm{H}, \mathrm{N}-\mathrm{H}), 7.04-7.99(\mathrm{~m}, 6 \mathrm{H}, \mathrm{Ar}-\mathrm{H})$, 11.28 (s, 1H, OH). ${ }^{13} \mathrm{C}-\mathrm{NMR}$ (100MHz, DMSO-d6): $\delta 169.35$ $(\mathrm{C}=\mathrm{O}), 168.21(\mathrm{C}=\mathrm{O}), 168.08(\mathrm{~N}=\mathrm{C}), 165.54,146.13,145.47$, $145.17,145.05,143.13,123.88,122.82,117.19,116.95$, $115.33,114.83$ (aromatic carbons), $83.39(\mathrm{C}), 77.46(\mathrm{C}), 74.90$ $\left(\mathrm{CH}_{2}\right), 67.58\left(\mathrm{CH}_{2}\right), 43.15\left(\mathrm{CH}_{3}\right), 40.05\left(\mathrm{CH}_{3}\right), 33.64\left(\mathrm{CH}_{3}\right)$, $31.45\left(\mathrm{CH}_{3}\right), 29.45\left(\mathrm{CH}_{3}\right), 25.47\left(\mathrm{CH}_{3}\right)$.

2-(3-oxo-2H-benzo[b] [1,4]oxazin-4(3H)-yl)- $N^{\prime}-(2,4,6-$ trimethoxybenzylidene) acetohydrazide (4e)

Yellow powder; Yield: method A $(70 \%)$ and method B (77\%); Mp: $141-242^{\circ} \mathrm{C}$. IR (KBr, cm $\left.{ }^{-1}\right): 1573,1593,1598$, 1612, 1670, 1701, 2962, 3055, 3193. ${ }^{1} \mathrm{H}-\mathrm{NMR}(400 \mathrm{MHz}$, DMSO- $\left.d_{6}\right): \delta 3.91 \quad\left(\mathrm{~s}, \quad 9 \mathrm{H}, \quad 3 \mathrm{OCH}_{3}\right), 4.74 \quad(\mathrm{~s}, \quad 2 \mathrm{H}$, $\mathrm{CH}_{2} \mathrm{CONHNH}-, \mathrm{CH}_{2}$ ), 5.15 (s, $2 \mathrm{H},-\mathrm{NCO}-\mathrm{CH}_{2} \mathrm{O}-, \mathrm{CH}_{2}$ ), 6.13$7.28(\mathrm{~m}, 6 \mathrm{H}, \mathrm{Ar}-\mathrm{H}), 8.10(\mathrm{~s}, 1 \mathrm{H}, \mathrm{N}=\mathrm{CH}$, azomethine $), 8.68(\mathrm{~s}$, $1 \mathrm{H}, \mathrm{N}-\mathrm{H}) .{ }^{13} \mathrm{C}-\mathrm{NMR}(100 \mathrm{MHz}, \mathrm{DMSO}-d 6): \delta 168.29(\mathrm{C}=\mathrm{O})$, $165.14(\mathrm{C}=\mathrm{O}), 163.75(\mathrm{~N}=\mathrm{C}), 153.84,152.78,147.74,139.94$, $129.56,123.26,117.11,116.84,115.92,113.75,110.06$, 109.82 (aromatic carbons), $88.12\left(\mathrm{O}-\underline{\mathrm{CH}}_{3}\right), 82.19\left(\mathrm{O}-\underline{\mathrm{CH}}_{3}\right)$, $79.53\left(\mathrm{O}-\mathrm{CH}_{3}\right), 55.95\left(\mathrm{CH}_{2}\right), 67.66\left(\mathrm{CH}_{2}\right)$.

2-(3-oxo-2H-benzo[b][1,4]oxazin-4(3H)-yl)- $N^{\prime}-(3,4,5-$ trimethoxybenzylidene) acetohydrazide (4f)

Yellow powder; Yield: method A (74\%) and method B (87\%); Mp: $249-250^{\circ} \mathrm{C}$; IR $\left(\mathrm{KBr}, \mathrm{cm}^{-1}\right): 1581,1608,1677$, 2943, 2974, 3186. ${ }^{1} \mathrm{H}-\mathrm{NMR}\left(400 \mathrm{MHz}, \mathrm{DMSO}-d_{6}\right): \delta 3.93$ (s, $\left.9 \mathrm{H}, 3 \mathrm{OCH}_{3}\right), 4.76\left(\mathrm{~s}, 2 \mathrm{H}, \mathrm{CH}_{2} \mathrm{CONHNH}-, \mathrm{CH}_{2}\right), 5.17(\mathrm{~s}, 2 \mathrm{H}$, -NCO- $\left.\mathrm{CH}_{2} \mathrm{O}-, \mathrm{CH}_{2}\right), 6.15-7.24(\mathrm{~m}, 6 \mathrm{H}, \mathrm{Ar}-\mathrm{H}), 8.11(\mathrm{~s}, 1 \mathrm{H}$, $\mathrm{N}=\mathrm{CH}$, azomethine), $8.88(\mathrm{~s}, 1 \mathrm{H}, \mathrm{N}-\mathrm{H}), 6.15-7.24(\mathrm{~m}, 6 \mathrm{H}, \mathrm{Ar}-$ H). ${ }^{13} \mathrm{C}-\mathrm{NMR}(100 \mathrm{MHz}$, DMSO-d6): $\delta 168.27(\mathrm{C}=\mathrm{O}), 165.18$ $(\mathrm{C}=\mathrm{O}), \quad 162.75 \quad(\mathrm{~N}=\mathrm{C}), \quad 153.84, \quad 152.78, \quad 147.74,139.94$, 
$129.55,123.26,117.12,116.84,115.94,113.57,111.06$, 108.82 (aromatic carbons), $86.15\left(\mathrm{O}-\mathrm{CH}_{3}\right), 83.33\left(\mathrm{O}-\mathrm{CH}_{3}\right)$, $78.29\left(\mathrm{O}-\mathrm{CH}_{3}\right), 59.95\left(\mathrm{CH}_{2}\right), 67.65\left(\mathrm{CH}_{2}\right)$.

\section{Biological study}

Antimicrobial activity

The synthesized compounds (4a-4f) were screened for their in vitro antibacterial and antifungal activities, against two pathogenic Gram-negative bacteria (Escherichia Coli and Pseudomonas aeruginosa) and one Gram-positive bacteria (Staphylococcus aureus) as well as one fungal strain (Candida Albicans). Ampicillin, Pénicillin and Amphotericin-B were used as reference standards, and dimethylsulfoxide (DMSO) was used both as a solvent and as a control (no inhibition zone was observed in control). The minimum inhibitory concentration (MIC) of these compounds against all bacterial and fungal strains was determined by serial dilution method. Stock solutions of tested compounds with 500, 200, 100 and $50 \mu \mathrm{g} \cdot \mathrm{mL}^{-1}$ concentrations were prepared with DMSO solvent. The solutions of standard drugs Ampicillin, Pénicillin, Amphotericin-B were prepared in concentration of $10 \mu \mathrm{g} . \mathrm{mL}^{-}$ $1,6 \mu \mathrm{g} \cdot \mathrm{mL}^{-1}$ and $20 \mu \mathrm{g} \cdot \mathrm{mL}^{-1}$ respectively. The minimum inhibitory concentration was defined as the highest dilution showing complete inhibition of the tested strains. The comparison of the MICs (in $\mu \mathrm{g} \cdot \mathrm{mL}^{-1}$ ) of potent compounds and standard drugs against tested strains are summarized and classified as sensitive, intermediate or resistant. Activity was determined by measuring the diameter of the zone of inhibition in millimeters $(\mathrm{mm})$. The bacterial strains were incubated for $24 \mathrm{~h}$ at $37^{\circ} \mathrm{C}$, and fungi strains were incubated for $48 \mathrm{~h}$ at $37^{\circ} \mathrm{C}$.

\section{RESULTS AND DISCUSSION}

\section{Chemistry}

The desired hydrazone derivatives were prepared according to the synthesis general pathway as shown in Scheme 1, using both conventional and Ultrasound-assisted methods. The starting material, 1,4-benzoxazin-3-(4H)-one
(1) was prepared according to the reported procedures from chloroacetyl chloride and appropriate 2-aminophenol. ${ }^{33 a} \mathrm{~N}$-Alkylation of 1,4benzoxazin-3-(4H)-one (1) with ethyl bromoacetate in the presence of $\mathrm{K}_{2} \mathrm{CO}_{3}$ in acetone (method $\left.\mathbf{A}\right)$ or DMF (method B) led to the formation of ethyl (3oxo-2,3-dihydro-4H-1,4-benzoxazin-4-yl)acetate (2). ${ }^{33 b}$ The acid hydrazide (3) was prepared by the reaction of ethyl (3-oxo-2,3-dihydro-4H-1,4benzoxazin-4-yl)acetate (2) with hydrazine hydrate in ethanol with good yield (83\%). In the final step, compounds $(\mathbf{4 a - 4 f )}$ were obtained by condensing acid hydrazide (3) with appropriate aromatic aldehydes in ethanol at reflux, with yields ranging from $55-88 \%$ when synthesized by conventional method (method A). On the other hand, the use of the ultrasound irradiations under catalyst-free condition (method B) has resulted in the formation of the desired benzoxazinonylhydrazone derivatives with a short reaction time (6-7 minutes) and good to excellent yields (60-94\%). The comparative study for ultrasound irradiation method as well as conventional heating, and the physicochemical data of the synthesized compounds are presented in Table 1.

For the prepared hydrazone derivatives $(\mathbf{4 a}-\mathbf{4 f})$, reaction time and yields are much better by using ultrasound irradiation compared to conventional heating. Therefore, ethanol was preferred as solvent for both conventional heating and ultrasound irradiation. Thin layer chromatography (TLC) was used for the purity characterization for the synthesized hydrazone products. The chemical structures of the synthesized compounds were consistent with their FT-IR as well as ${ }^{1} \mathrm{H}-\mathrm{NMR}$ and ${ }^{13} \mathrm{C}$-NMR spectroscopic data (details in the Experimental part).

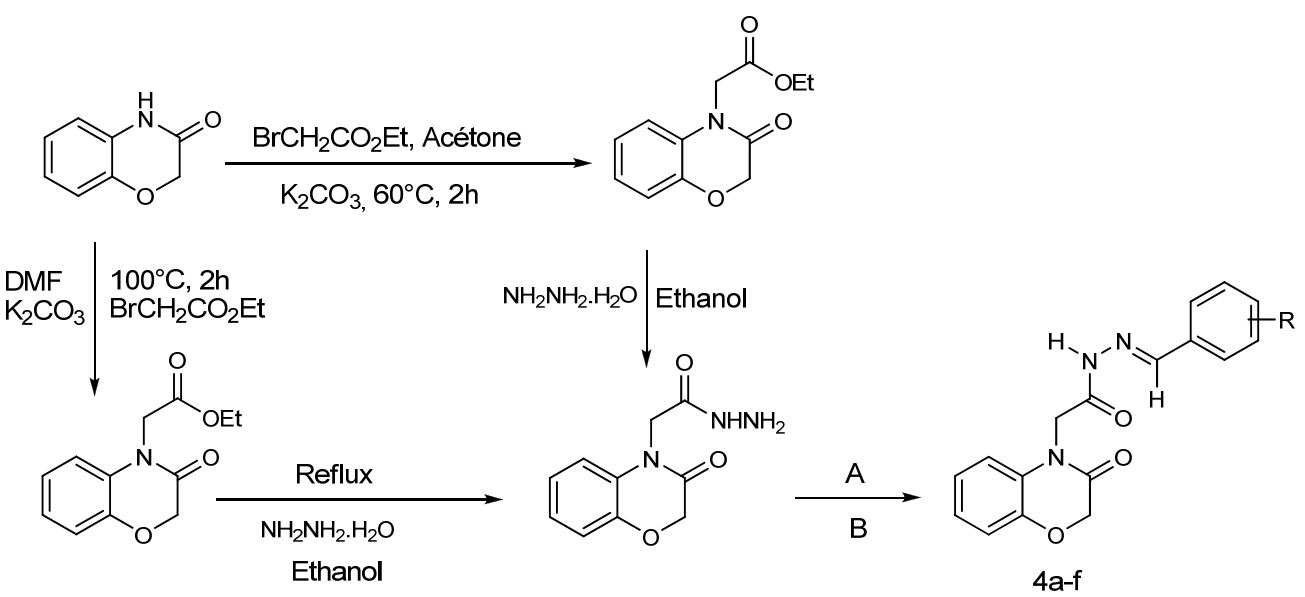

Scheme 1 - Synthesis of the target hydrazones; Reagents and conditions: A: Method A, Conventional heat, reflux, absolute ethanol, glacial acetic acid, $35 \mathrm{~min}$; B: Method B, Ultrasound irradiations, catalyst-free, absolute ethanol, 6-7 min. 
Table 1

Comparative study of the synthesized hydrazone compounds (4a-4f)

\begin{tabular}{|c|c|c|c|c|c|}
\hline Product & $\mathbf{R}$ & ${ }^{\mathrm{a}} \mathrm{Mp}\left({ }^{\circ} \mathrm{C}\right)$ & \begin{tabular}{c}
\multicolumn{2}{c}{$\mathbf{C H}$} \\
Time ${ }^{\mathbf{b}}$ Yield \\
$(\mathrm{min}) \quad(\%)$
\end{tabular} & $\begin{array}{c}\text { Us } \\
\text { Time } \\
(\mathrm{min}) \\
\end{array}$ & $\begin{array}{l}\mathbf{S} \\
{ }^{\mathrm{c}} \text { Yield } \\
(\%) \\
\end{array}$ \\
\hline $4 \mathbf{a}$ & $2-\mathrm{OH}$ & $270-271$ & $35 \quad 88$ & 6 & 94 \\
\hline $4 b$ & $5-\mathrm{Cl}, 2-\mathrm{OH}$ & 290-291 & 74 & 6 & 86 \\
\hline $4 c$ & 3,5-dit-2-OH & $226-227$ & 55 & 7 & 60 \\
\hline 4d & 3,5-dit-4-OH & $240-241$ & 79 & 6 & 91 \\
\hline $4 e$ & $2,4,6-\mathrm{OCH}_{3}$ & $241-242$ & 70 & 7 & 77 \\
\hline $4 f$ & $3,4,5-\mathrm{OCH}_{3}$ & $249-250$ & 35 & 6 & 87 \\
\hline
\end{tabular}

Notes: ${ }^{\text {a Melting point; }}{ }^{\mathbf{b}, \mathbf{c}}$ Isolated yield; CH: Conventional heat; US: Ultrasound irradiation.

The FT-IR spectra analysis of all compounds (4a-4f) showed a characteristic absorption bands, by the disappearance of the $\mathrm{C}-\mathrm{O}$ stretching band at $1153 \mathrm{~cm}^{-1}$ and the presence of the strong band in the region $1684-1701 \mathrm{~cm}^{-1}$, due to a carbonyl group of amide $v(\mathrm{C}=\mathrm{O})$ derived from the hydrazone structure instead of a $\mathrm{C}=\mathrm{O}$ stretching band at $1738 \mathrm{~cm}^{-1}$, is a good evidence for the presence of an azomethine linkage. Other functional groups $\left(\mathrm{NH}, \mathrm{OH}, \mathrm{CH}_{2}, \mathrm{CH}_{3}\right.$ and $\mathrm{OCH}_{3}$ ) were also detected well. Furthermore, ${ }^{1} \mathrm{H}-\mathrm{NMR}$ spectra of all studied compounds revealed the presence of the aromatic protons in the region of $\delta$ from 6.13 to 7.99. Signals for the protons of the azomethine group $-\mathrm{NH}-\mathrm{N}=\mathrm{CH}-$ (characteristic for hydrazone Schiff bases) were observed between $\delta$ 8.11-8.85 ppm. ${ }^{13} \mathrm{C}-\mathrm{NMR}$ spectra demonstrated signals corresponding to the carbon atoms of azomethine group between $\delta 162.75$ and 163.45. The peaks at $\delta 165.05-169.53 \mathrm{ppm}$ were assigned to the $\mathrm{C}=\mathrm{O}$ group.

\section{Antimicrobial studies}

We have synthesized hydrazone derivatives having benzoxazinone ring (4a-4f), to develop new potential antimicrobial agents. The in vitro antimicrobial activity of the synthesized compounds was evaluated, using the broth microdilution method against two representative Gram-negative bacteria (Escherichia coli and Pseudomonas aeruginosa) and Gram positive bacteria staphylococcus aureus as well as fungal strains $C$. albicans. The results of the minimum inhibitory concentration (MIC) as well as the zone of inhibition values of the tested compounds are presented in Table 2. They revealed that most of the newly synthesized compounds exhibited promising antifungal activities, whereas poor antibacterial activities have been observed.

\section{Antibacterial activity}

The newly synthesized compounds were screened for their antibacterial activity against Escherichia coli, Staphylococcus aureus and Psuedomonas aeruginosa bacterial strains by disc diffusion method. It has been observed that Pseudomonas aeruginosa has developed resistance against the all synthesized derivatives at 50-500 $\mu \mathrm{g} . \mathrm{mL}^{-1}$ concentrations. Furthermore, Escherichia coli was found to be resistant against all the synthesized derivatives except 4a with 2-hydroxy substitution. Also, it should be noted that the compounds $\mathbf{4 b}-\mathbf{4} \mathbf{f}$ were not active against Escherichia coli. Most of them were found to be inactive against $E$. coli and Psuedomonas aeruginosa. The compounds $\mathbf{4 a}, \mathbf{4 c}, \mathbf{4 d}, \mathbf{4 e}$ and compound $\mathbf{4 f}$ at the same concentrations were also characterized by moderate activity, while compounds 4b with 5-Chloro, 2-hydroxy substitution was found not active against Staphylococcus aureus.

\section{Antifungal activity}

In the case of antifungal study, the newly prepared compounds were screened for their antifungal activity against Candida albicans. From the obtained results, it is clear that all these compounds possess moderate to good antifungal activity (MIC 50-500 $\mu \mathrm{g} \cdot \mathrm{mL}^{-1}$ ) against Candida albicans as compared to Amphotericine-B. Compounds 2-hydroxy substituted derivative $\mathbf{4 a}$ (14-24 mm at 50-500 $\left.\mu \mathrm{g} \cdot \mathrm{mL}^{-1}\right), 4$ b with a 5Chloro-2-hydroxy substitution (14-22 $\mathrm{mm}$ at 50$500 \mu \mathrm{g} \cdot \mathrm{mL}^{-1}$ ) and $4 \mathrm{e}$ with a 2,4,6-trimethoxy substitution $\left(10-23 \mathrm{~mm}\right.$ at $\left.50-500 \mu \mathrm{g} \cdot \mathrm{mL}^{-1}\right)$ have emerged as the most active products. 
Table 2

Antibacterial and antifungal activity (zone of inhibition in $\mathrm{mm}$ ) of compounds $\mathbf{4 a}-\mathbf{4 h}$

\begin{tabular}{|c|c|c|c|c|c|c|c|c|c|c|}
\hline \multirow{3}{*}{$\begin{array}{c}\text { Bacterial and } \\
\text { Fungal } \\
\text { species }\end{array}$} & \multirow{3}{*}{$\begin{array}{l}\text { Concentration } \\
\left(\mu \mathrm{g} \cdot \mathrm{mL}^{-1}\right)\end{array}$} & \multirow{2}{*}{\multicolumn{6}{|c|}{$\frac{\text { Compounds }}{\text { IZD }(\mathrm{mm})}$}} & \multicolumn{3}{|c|}{ Standards } \\
\hline & & & & & & & & $\mathbf{A}$ & $\mathbf{P}$ & \\
\hline & & $4 a$ & $4 b$ & $4 c$ & 4d & $4 e$ & $4 f$ & $10 \mu \mathrm{g} \cdot \mathrm{mL}^{-1}$ & $6 \mu \mathrm{g} \cdot \mathrm{mL}^{-1}$ & $20 \mu \mathrm{g} \cdot \mathrm{mL}^{-1}$ \\
\hline \multirow[t]{4}{*}{ S. aureus } & 500 & 10 & - & 15 & 08 & 11 & 08 & 24 & 22 & - \\
\hline & 200 & 07 & - & 13 & 06 & 09 & 05 & & & \\
\hline & 100 & 06 & - & 07 & - & 05 & 04 & & & \\
\hline & 50 & 05 & - & - & - & - & - & & & \\
\hline \multirow[t]{4}{*}{ E. coli } & 500 & 13 & - & - & - & - & - & 16 & - & - \\
\hline & 200 & 10 & - & - & - & - & - & & & \\
\hline & 100 & 08 & - & - & - & - & - & & & \\
\hline & 50 & - & - & - & - & - & - & & & \\
\hline \multirow[t]{4}{*}{ P. aeruginosa } & 500 & - & - & - & - & - & - & - & - & - \\
\hline & 200 & - & - & - & - & - & - & & & \\
\hline & 100 & - & - & - & - & - & - & & & \\
\hline & 50 & - & - & - & - & - & - & & & \\
\hline \multirow[t]{4}{*}{ C. albicans } & 500 & 24 & 22 & 12 & 11 & 23 & 13 & - & - & 13 \\
\hline & 200 & 21 & 20 & 10 & 09 & 20 & 11 & & & \\
\hline & 100 & 18 & 17 & 09 & 06 & 16 & 08 & & & \\
\hline & 50 & 14 & 14 & 08 & 05 & 10 & - & & & \\
\hline
\end{tabular}

Notes: A: Ampicillin, P: Pénicillin, A-B: Amphotericin-B; -: No sensitivity; IZD: Inhibition zone diameter (mm).

\section{CONCLUSIONS}

In conclusion, we have successfully synthesized and characterized a new series of novel biologically significant benzoxazinone-based hydrazone derivatives, by condensation of different substituted aromatic benzaldehydes and benzoxazinonylhydrazide under green aspects, using ultrasound irradiations without any catalyst as well as conventional heating methods to give the desired products. The ultrasound method affords good to excellent yield of the isolated compounds, in shorter reaction times with no by-products. Furthermore, the in vitro antimicrobial activities against bacterial strains $E$. coli, $P$. aeruginosa and $S$. aureus as well as fungal strains $C$. albicans of these compounds were investigated. All of these compounds exhibited remarkable antifungal activity against $C$. albicans. They showed moderate antibacterial activity against $S$. aureus, as Gram-positive bacteria, and most of them were found to be inactive against $E$. coli and $P$. aeruginosa. Thus, the present study has expanded the scope for developing these derivatives as promising antifungal agents. Therefore, it can be concluded that these compounds merits further investigation, and may serve as a basis for the chemical modifications directed towards the development specifically of a new class of antifungal agents.

Acknowledgements: This research work was financially supported by Algerian Ministry of Higher Education and Scientific Research (MESRS) under the project number:
CNEPRU-E01120140064 as part of Ph.D thesis of Naouel CHETTIBI. The authors would like to thank Prof. Cherif Abdennour, Laboratory of Animal Ecophysiology, University of BADJI Mokhtar-Annaba, for critically reading the manuscript and helpful discussions.

\section{REFERENCES}

1. J. M. Frere, Mol. Microb., 1995, 16, 385-395.

2. Ł. Popiołek and A. Biernasiuk, Saudi Pharm J., 2017, 25, 1097-1102.

3. D. D. Mukherjee, N. M. Kumar, M. P. Tantak, A. Das, A. Ganguli, S. Datta, D. Kumar and G. Chakrabarti, Biochemistry, 2016, 55, 3020-3035.

4. Ş.G. Küçükgüzel, D. Koç, P. Çıkla, D. Özsavcı, Ö. Bingöl-Özakpınar, P. Mega-Tiber, O. Orun, P. Erzincan, S. S. Erdem and F. Şahin, Arch. Pharm. Chem. Life. Sci., 2015, 348, 730-742.

5. B. I. Nikolova-Mladenova and S. E. Angelova, Bulg. Chem. Commun., 2017, 49, 800-806.

6. D. Sarıg̈l, D. Yüksel, G. Okay and A. Uzgören-Baran, J. Mol. Struct., 2015, 1086, 146-152.

7. T. T. Tok, Ö. Özaşik, D. S. Ayşe and U. Baran, Turk. J. Chem., 2015, 39, 64-83.

8. Y. P. Kitaev, B. I. Buzykin and T. V. Troepolskaya, Russ. Chem. Rev., 1970, 39, 441-456.

9. T. Hökelek, S. Bilge and Z. Kili , Analytical Sciences: $X$-Ray Structure Analysis Online, 2006, 22, 143-144.

10. Ng. Ph. Buu-Hoi, D. Xuong, H. Nam, F. Binon and R. Royer, J Chem Soc., 1953, 12, 1358-1364.

12. S. Jubie, S. Meena, K.V. Ramaseshu, N. Jawahar and S. Vijayaku, Indian J. Heterocycl. Chem., 2010, 49B, 1261-1263.

13. D. Mantu, V. Antoci, A. Nicolescu, C. Deleanu, V. Vasilache and I. I. Mangalagiu, Curr. Org. Synth., 2017, 14, 112-119.

14. D. Mantu, V. Antoci and I. I. Mangalagiu, Infect Disord. Drug Targets, 2013, 13, 344-351. 
15. D. Mantu, C. Moldoveanu, A. Nicolescu, C. Deleanu, V. Antoci and I. I. Mangalagiu, Ultrason. Sonochem., 2009, 16, 452-454.

16. V. B. Shashikant, G. B. Kailash, K. R. Mayuresh, A. P. Ajit, P. S. Aniket and J. M. Vinod, Bioorg. Med. Chem., 2008, 16, 1822-1831.

17. S. M. Sondhi, M. Dinodia and A. Kumar, Bioorg Med Chem., 2006, 14, 4657-4663.

18. A. S. Alp, G. Kilcigil, E. D. Özdamar, T. Çoban and B. Eke, Turk. J. Chem., 2015, 39, 42-53.

19. M. Soujanya, G. Rajitha, A. Umamaheswari and K. S. Kumar, Lett Drug Des Discov., 2018, 15, 875-886.

20. A. K. Singh, S. Thakur, B. Pani, E. E. Ebenso, M. A. Quraishi and A. K. Pandey, ACS Omega, 2018, 3, 4695-4705.

21. G. Cravotto and P. Cintas, Chem. Soc. Rev., 2006, 35, 180-196.

22. T. J. Mason, Chem. Soc. Rev., 1997, 26, 443-451.

23. M. Nüchter, B. Ondruschka, A. Jungnickel and U. Müller, J. Phys. Org. Chem., 2000, 13, 579-586.

24. D. E. Crawford, Beilstein J. Org. Chem., 2017, 13, 18501856.

25. S. Puri, B. Kaur, A. Parmar and H. Kumar, Curr. Org. Chem., 2013, 17, 1790-1828.

26. X. Fan, F. Chen and X. Wang, J. Oleo Sci., 2010, 59, 235-241.

27. D. Vidya and S. Rachana Int. J. Pharm., 2015, 5, 930935.

28. G. Zbancioc, I. I. Mangalagiu and C. Moldoveanu, Ultrason. Sonochem., 2015, 23, 376-383.

29. G. Zbancioc, A. M. Zbancioc and I. I. Mangalagiu, Ultrason. Sonochem., 2014, 23, 802-811.

30. G. Zbancioc, O. Florea, P. Jones and I. I. Mangalagiu, Ultrason. Sonochem., 2012, 19, 399-403.

31. V. Bejan, D. Mantu and I. I. Mangalagiu, Ultrason. Sonochem., 2012, 19, 999-1002.

32. V. Bejan, C. Moldoveanu and I. I. Mangalagiu, Ultrason. Sonochem., 2009, 16, 312-315.

33. (a) T. B. Ravi, N. Lingaiah and B. Rajeeva, Int. Res. J. Pharm., 2017, 8, 23-28. (b) N. Chettibi, H. Bentoumi and M. Liacha, Sci. Bull., Series B, 2018, 80, 148-158.

34. G. Sonia, K. K. Thachil, M. K. Parameswaran and R. T. Kochupappy, Med. Chem. Res., 2014, 23, 1320-1326.
35. Y. Matsumoto, W. Uchida, H. Nakahara, I. Yanagisawa, T. Shibanuma and H. Nohira, Chem Pharm Bull., 2000, 48, 428-432.

36. S. Alper-Hayta, E. Aki-Sener, B. Tekiner-Gulbas, I. Yildiz, O. Temiz-Arpaci, I. Yalcin and N. E. Altanlar, Eur. J. Med. Chem., 2006, 41, 1398-1404.

37. B. C. Das, A.V. Madhukumar, J. Anguiano and S. Mani, Bioorg. Med. Chem. Lett., 2009, 19, 4204-4206.

38. M. Z. Huang, F. X. Luo, H. B. Mo, Y. G. Ren, X. G. Wang, X. M. Ou, M. X. Lei, A. P. Liu, L. Huang and M. C. Xu, J. Agric. Food Chem., 2009, 57, 9585-9592.

39. T. Hasui, N. Ohyabu, T. Ohra, K. Fuji, T. Sugimoto, J. Fujimoto, K. Asano, M. Oosawa, S. Shiotani, N. Nishigaki, K. Kusumoto, H. Matsui, A. Mizukami, N. Habuka, S. Sogabe, S. Endo, M. Ono, C. S. Siedem, T. P. Tang, C. Gauthier, L. A. De Meese, S. A. Boyd and S. Fukumoto, Bioorg. Med. Chem., 2014, 22, 5428-5445.

40. T. R. F. de Melo, R. C. Chelucci, M. E. L. Pires, L. A. Dutra, K. P. Barbieri, P. L. Bosquesi, G. H. G. Trossini, M. C. Chung and J. L. dos Santos, Int. J. Mol. Sci., 2014, 15, 5821-5837.

41. M. Largeron, B. Lockhart, B. Pfeiffer and M. B. Fleury, J Med Chem., 1999, 42(24), 5043-5052.

42. V. Sharma, P.K. Jaiswal, D.K. Yadav, M. Saran, J. Prikhodko, M. Mathur, A.K. Swami, I.V. Mashevskaya and S. Chaudhary, S. Acta Chim. Slov., 2017, 64(4), 9881004.

43. M. Śmist, M. Krawczyk and H. Kwiecien, Environ. Sci. Health B., 2016, 51, 393-401.

44. H. B. Borate, S. R. Maujan, S. P. Sawargave, M. A. Chandavarkar, S. R. Vaiude, V. A. Joshi, R. D. Wakharkar, R. Iyer, R. G. Kelkar, S. P. Chavan and S. S. Kunte, Bioorg. Med. Chem. Lett., 2010, 20, 722-725.

45. R. Fringuelli, D. Pietrella, F. Schiaffella, A. Guarraci, S. Perito, F. Bistoni and A. Vecchiarilli, Bioorg. Med. Chem. Lett., 2002, 10, 1681-1686.

46. T. Govindasami, A. Pandey, N. Palanivelu and A. Pandey, Int. J. Org. Chem., 2011, 1, 71-77.

47. F. A. Macías, D. Marín, A. Oliveros-Bastidas, D. Castellano, A. M. Simonet and J. M. G. Molinillo, J. Agric. Food Chem., 2005, 53, 538-48.

48. A. H. Collins, "Microbiological Methods", $2^{\text {nd }}$ edition, Butterworth, London, 1976. 
